\title{
NOTES FROM THE BOTANIC GARDENS, SYDNEY.
} Parthenogenesis in Aquatic Phanerogams.

By A. H. S. Lucas, M.A., B.Sc.

\section{Elatine triandra Schrank [Elatinacea].}

Plants of Elatine were brought under my notice by Mr. J Brooks, who has charge of the freshwater aquaria at the Botanic Gardens, Sydney, in February last. The plants were growing submerged in a glass tank. They had grown vigorously for some months, with roots fixed in the soil at the bottom of the tank. Now, fragments were being detached freely, with rootlets growing out into the water. Mr. Brooks wanted to know - "Why are the plants breaking up in this way?"

Capsules in various stages of development were growing on the plants, but no flowers or flower-buds could be discovered. There were no signs of calyx-lobes, corolla, stamens, or even bracts. A few of these capsules contained apparently fully developed, brown seeds presenting the characteristic sculpturing.

Thinking that by modifying the conditions we might be able to induce normal flowering, I asked Mr. Brooks to plant some in earth in a flower-pot surrounded by water, and to expose these gradually to full sunlight.

A few days later, I discovered the plant growing in the LilyPond of the Centennial Park, Sydney. Large, floating fragments, up to 9 inches in length, with abundant roots, bore fruits similar to those formed in the tank. At one spot, the floor of the pond was dry, owing to the prolonged drought. Here the plant was growing on firm mud. The leaves were very much shorter, and the plant altogether smaller, than in the submerged form; but it bore numerous, small flowers, with 3 , broad, green sepals; 3 , spreading, red pistils; and 3 stamens I brought some home, with the surrounding mud, and planted them in an ordinary flower-pot. I did not place the pot in water, but kept 
it well watered, and exposed it to sunlight. The plants spread, and continued to flower well into the month of May. Mr. Brooks' plants naturally took longer to accustom themselves to the greater change of conditions, but, early in April, they were in full flower. Thus, the suggested experiment had succeeded. It was plain that the condition necessary to produce flowers was exposure of the growing plant to air and sunlight.

I then tried the converse experiment of placing some of the flowering plants in soil, at the bottom of a glass jar, which I filled with water. They did not resent the sudden change, but speedily grew out into the elongated form with longer leaves, and now (in May) are producing the capsules of the submerged form freely.

The capsules of the submerged form closely resemble those of the flowers, and, as no stamens are present, we have a clear case of parthenogenesis.

\section{Glossostigma spathulatum Arnott [Scrophulariacee].}

In another glass tank in the Gardens, were growing vigorously, a number of plants of a Glossostigma, which, while spreading freely in the water, never rose to the surface. The roots were fixed in the soil at the bottom. These plants also bore capsules of various stages, in none of which could I detect floral envelopes or stamens. The plants had been growing for years in the tank, but had never produced flowers.

We experimented with these in the same way as with Elatine. Mr. Brooks placed his in a flower-pot in ordinary mould, and placed the pot in a large saucer filled with water. In about a month, the plants had quite accommodated themselves to the new habitat, and produced a number of tiny, blue, perfect flowers. I arranged my plant in a diminutive, artificial pond I had made, so that part of the creeping stem was fixed by the roots to soil at the bottom, and the other part, unsevered, extended over a small bank of earth at the side of the pond. Thus, part of the plant was submerged, and part exposed to air and direct sunlight. It seemed at home at once, and both plants grew quickly. The submerged part spread far and wide over 
the bottom of the pond, and formed capsules; and, in less than a fortnight, the terrestrial portion had spread over the bank (which was now and again inundated, when the pond was filled up) and formed the fully developed, blue flowers. The number of stamens was constantly 2, and, therefore, our plant must be placed as $G$. spathulatum Arnott. The other Australian species, $G$. Drummondii Benth., and $G$. elatinoides Benth., have 4 stamens.

It was naturally a pleasure to have thus succeeded in obtaining the normal flowers. Curiously, perhaps the only passage in the severe pages of the Flora Australiensis which is "tinged with emotion," occurs in relation with this plant. Bentham quotes a remark of O'Shanesy, who gathered this species at Rockhampton, that "the numerous little blue flowers look like tiny drops of dew." (Vol. iv., p.502).

We had thus succeeded in inducing flowering in both plants. In a submerged state, they do not produce a distinct calyx, petals or stamens, but freely produce capsules. To test the fertility of the seeds produced in the submerged capsules of Glossostigma, I asked Mr. Brooks to sow the seeds. He placed some in soil exposed to air, and dropped some on to the soil at the bottom of a tank containing water. Both sets germinated, the latter with extreme freedom.

Thus habitual parthenogenesis is seen to occur in Glossostigma spathulatum - so long as the plant remains entirely submerged. When the plants obtain a footing on mud uncovered with water, they will develop flowers in the season, and produce ovules fertilised in the usual way. Incidentally, we may find a reasonable answer to Mr. Brooks' original question in regard to Elatine. The submerged plant tends to break up into fragments or sections in the season proper for flowering. These fragments float, and, as we saw in the pond in the Centennial Park, under natural conditions will have a chance of reaching a mooring ground, and thus of attaining to a terrestrial habitat convenient for flowering.

We have not yet experimented with the seeds of Elatine, produced in the submerged capsules, but the mature form of the seeds found makes it nearly certain that they are fertile. 
These two instances of parthenogenesis in two, submerged plants of so widely separated families seem to lead up to the conception, that such a habit is likely to be very generally char acteristic of plants growing under similar conditions. At all events, I have obtained considerable evidence in favour of this view. Further investigation is in progress, and I hope to bring further results before the Society, as opportunity occurs for experimentation.

\section{Note on the Species of Elatine.}

The plant experimented on is our common Elatine. The Southern species, in which Bentham includes the Australian form, has been labelled E. minima Fisch. \& Meyer, (Linnæa, x., 73), E. gratioloides A. Cunn., (Ann. Nat. Hist., iii., 26, on New Zealand forms), E. americana Arnott, by von Mueller, and $E$. americana Arnott, var. australiensis by Bentham. E. trianara of Schrank was founded in 1791; and E. americana Arnott, in 1814 .

Bentham says "The Australian species is considered by some as endemic, by others as identical with an American one." And again, "This plant, whether a distinct species or a variety of the N. American one, . . . . . is very variable." He then notes various forms, those under water with elongated stems, and very few with petals. There is no doubt that the external form varies at once, as we have seen, even in the same individual, when the conditions change.

Britton and Brown, in their "Illustrated Flora of the Northern United States," 1897, ii., p.437, give descriptions and figures of both $E$. americana and E.triandra. Of $E$. americana they state, "Sepals, petals, stamens, styles 2 (rarely 3 in terrestrial forms)"; and of E. triandra, "Sepals commonly 2; petals, stamens, and stigmas 3." In our specimens, the trimerism of all the parts is conspicuous. Thus Bentham writes $(l c$.$) , "The N. American$ plant" [i.e., E. americana] "differs chiefly in the flowers almost constantly dimerous, which does not occur in any southern specimens I have examined."

Inasmuch as the number of stamens present in the flowers is 
one of the chief points relied on in the differentiation of species of Elatine, the discrepancy in the numbers seems fatal to the inclusion of our plants, with flowers almost constantly trimerous, in $E$. americana, with flowers almost constantly dimerous. On the other hand, there is much less reason for separating the Australian form from the older species, E. triandra.

I have been able to compare our plants with specimens, in the Herbarium of the Botanic Gardens, of $E$. americana and $E$. triandra, both from the United States. The facies of the Australian form agrees well enough with either-as do the dimensions of parts-but the predominance of trimerism of parts brings it into much closer relation with E. triandra. The differences appear to be too small to justify the creation of a new species, and I propose, therefore, to include our Elatine in $E$. triandra Schrank. 


\section{$2 \mathrm{BHL}$ Biodiversity Heritage Library}

Lucas, A. H. S. 1916. "Notes from the Botanic Gardens, Sydney. Parthenogenesis in aquatic phanerogams." Proceedings of the Linnean Society of New South Wales 41, 417-421. https://doi.org/10.5962/bhl.part.15320.

View This Item Online: https://www.biodiversitylibrary.org/item/22900

DOI: https://doi.org/10.5962/bhl.part.15320

Permalink: https://www.biodiversitylibrary.org/partpdf/15320

\section{Holding Institution}

MBLWHOI Library

\section{Sponsored by}

MBLWHOI Library

\section{Copyright \& Reuse}

Copyright Status: NOT_IN_COPYRIGHT

This document was created from content at the Biodiversity Heritage Library, the world's largest open access digital library for biodiversity literature and archives. Visit BHL at https://www.biodiversitylibrary.org. 